\title{
MENINGKATKAN KEMAMPUAN MENULIS PERMULAAN ANAK USIA 4-5 TAHUN MELALUI KEGIATAN FINGER PAINTING
}

\author{
Siti Riskayanti ${ }^{1}$, Suwardi $^{1}$ \\ ${ }^{1}$ Program Studi Pendidikan Guru Pendidikan Anak Usia Dini, Fakultas Psikologi dan \\ Pendidikan, Universitas Al-Azhar Indonesia, Komplek Masjid Agung Al- Azhar Jl. \\ Sisingamangaraja, Jakarta Selatan, 12110 \\ E-mail: $\underline{\text { suwardi@uai.ac.id }}$
}

\begin{abstract}
ABSTRAK: Penelitian ini bertujuan untuk meningkatkan kemampuan menulis permulaan pada anak Kelompok A TK Negeri Latihan II. Metode penelitian yang digunakan adalah tindakan kelas dengan model Kemmis dan Mc. Taggart. Subjek penelitian adalah anak kelompok A TK Negeri Latihan II yang berjumlah 19 anak terdiri dari 8 anak perempuan dan 11 anak laki-laki dengan rentang usia 4-5 tahun. Pengumpulan data dilakukan dengan menggunakan metode observasi, wawancara dan dokumentasi. Teknik analisa data dilakukan menggunakan statistik deskriptif sederhana. Penilaian kemampuan menulis permulaan anak dilihat dengan indikator kemampuan menulis huruf-huruf yang dicontohkan dengan cara meniru dengan kriteria Belum Berkembang (BB), Mulai Berkembang (MB), Berkembang Sesuai Harapan (BSH) dan Berkambang Sangat Baik (BSB). Anak dinyatakan mampu menulis permulaan jika telah mencapai kriteria Berkembang Sesuai Harapan (BSH) dan Berkembang Sangat Baik (BSB). Hasil penelitian menunjukan bahwa pembelajaran melalui kegiatan finger painting yang dilakukan selama 3 siklus dapat meningkatkan kemampuan menulis permulaan anak. Pada Siklus III kriteria Belum Berkembang (BB) sebesar 0\%; kriteria Mulai Berkembang (MB) sebesar 12.28\%; dan kriteria Berkembang Sesuai Harapan (BSH) sebesar 33.33\%. Sementara kriteria Berkembang SangatBaik (BSB) mengalami peningkatan sebesar 54.39\%. Hal tersebut menunjukkan bahwa kegiatan finger painting dapat meningkatkan kemampuan menulis permulaan anak usia 5-6 tahun.
\end{abstract}

Kata Kunci: menulis permulaan, finger painting, anak usia 5-6 tahun

ABSTRACT: This study aims to improve the writing ability of the beginning in children in Group A TK Negeri Exercise II. The research method used was class action with the Kemmis and Mc models. Taggart. The research subjects were children of group A TK Negeri Exercise II, amounting to 19 children consisting of 8 girls and 11 boys with ages 4-5 years. Data collection is done using the method of observation, interviews and documentation. Data analysis techniques were carried out using simple descriptive statistics. The assessment of the child's writing ability is seen by the indicators of the ability to write letters that are exemplified by imitating the criteria of Not Developing (BB), Starting to Develop (MB), Developing according to Expectations (BSH) and Building Excellent (BSB). Children are stated to be able to write the beginning if they have achieved the Expectation (BSH) and Excellent Development (BSB) criteria. The results of the study show that learning through finger painting activities carried out for 3 cycles can improve the writing ability of the child's beginning. In Cycle III the criteria for Not Developing (BB) are 0\%; the Start Growing criteria (MB) is 12.28\%; and Expectation Expansion Criteria (BSH) of 33.33\%. While the Developing Criteria is Very Good (BSB) has increased by $54.39 \%$. This shows that the activity of finger painting can improve the writing ability of the beginning of children aged 5-6 years. 


\section{PENDAHULUAN}

\section{A. Latar Belakang}

$\mathrm{P}$ endidikan Taman Kanak-kanak diberikan pada anak agar dapat berkembang secara optimal. Mengingat pentingnya masamasa ini, maka peran stimulasi berupa penyediaan lingkungan yang kondusif harus disiapkan oleh para pendidik, orang tua, guru, pengasuh, dan orang dewasa yang berada di sekitar anak. Anak memiliki kesempatan untuk mengembangkan berbagai potensi baik psikis dan fisik yang meliputi moral dan nilai-nilai agama, sosio-emosional, kemandirian, kemampuan berbahasa, kognitif, fisik motorik, dan seni.

Salah satu potensi yang harus dikuasai oleh anak usia dini adalah kemampuan motorik. Kemampuan motorik dibedakan menjadi dua yaitu: 1). motorik kasar yang menekankan pada koordinasi tubuh yang menekankan pada gerakan otot-otot besar seperti berjalan, berlari, naik dan turun tangga dan melompat; dan 2). motorik halus, yang menekankan pada koordinasi otot tangan atau kelenturan tangan yang bersifat keterampilan seperti menulis, karena kemampuan menulis menutut keterampilan motorik halus yang melibatkan koordinasi jari dan mata seperti meggambar, memotong, meronce, melempar, dan menangkap bola, serta memainkan bendabenda atau alat-alat mainan. (Curtis, Hurlock, 2011: 105). Menulis merupakan salah satu kemampuan yang melibatkan motorik halus.

Menulis atau keaksaraan erat pula hubungannya dengan membaca, menyimak dan berbicara. Dengan melatih kemampuan menulis permulaan akan memudahkan anak untuk mengembangkan keterampilan bahasa yang baru muncul. Menurut Mundar (1999: 22), pendidikan anak usia dini adalah pemberian upaya untuk menstimulasi, membimbing, mengasuh dan pemberian kegiatan pembelajaran yang akan menghasilkan kemampuan dan keterampilan anak, salah satu kemampuan dan keterampilan yang dapat diberikan adalah kemampuan menulis. Kemampuan menulis pada anak memegang peran yang sangat penting, karena menulis adalah salah satu alat untuk berkomunikasi dengan orang lain. Proses perkembangan menulis tidak berhenti ketika anak mulai bersekolah atau ketika anak sudah mulai dewasa tetapi berkembang seiring berjalannya waktu. Maka beberapa kegiatan motorik halus sangat penting diberikan sebelum kegiatan menulis permulaan diberikan, agar otot anak menjadi lentur, dan anak tidak merasa bosan pada saat melakukan kegiatanmenulis.

Masih ada guru yang beranggapan bahwa keterampilan menulis akan tumbuh secara sendirinya, sehingga tidak diperlukan stimulasi yang diberikan kepada anak untuk meningkatkan kemampuan menulisnya. Menulis permulaan bagi anak-anak usia 4-5 tahun adalah kemampuan anak mengungkapkan diri dalam bentuk tertulis, mulai dari coret-coret, dan menggambargambar sampai mendekati bentuk huruf dan kata-kata (Seefeldt, 2008: 373). Jadi menulis bagi anak usia 4-5 tahun dimulai dari coretcoret, dan menggambar, kemudian anak membentuk huruf-huruf dan kata-kata. Fenomena yang terlihat di TK Negeri Latihan II, ditemukan beberapa anak yang masih kurang dalam kemampuan menulis permulaan. Salah satu hal yang terlihat adalah ketika anak memegang alat tulis dengan benar, kekuatan tangan dan kelenturan dalam menggerakan otot-otot kecil yang terdapat pada jarijemarinya yang masih kaku mengakibatkan hasil tulisan anak menjadi sulit dibaca. Dari 19 anak, baru 4 anak yang dapat menuliskan nama mereka sendiri dengan jelas.

Pada kegiatan ini peneliti melakukan modifikasi dalam melakukan kegiatan menulis permulaan. Kegiatan yang akan diberikan adalah kegiatan finger painting. Dipilihnya kegiatan ini dikarenakan finger painting merupakan kegiatan yang menggunakan motorik halus atau jari jemari sebagai modal dasar untuk melakukan kegiatan.

\section{B. Rumusan Masalah}

Berdasarkan latar belakang di atas maka permasalahan yang dapat dirumuskan adalah "bagaimana meningkatkan kemampuan menulis permulaan anak usia 4-5 tahun melalui kegiatan finger painting?

\section{Tujuan Penelitian}

Tujuan dari penelitian tindakan ini adalah untuk meningkatkan kemampuan menulis permulaan anak usia 4-5 tahun melalui kegiatan finger painting 


\section{Manfaat Hasil Penelitian}

Hasil penelitian ini diharapkan dapat bermanfaat bagi:

1. Orang Tua

Dengan hasil ini diharapkan dapat memberikan pemahaman bagi orang tua akan pentingnya kegiatan belajar melalui kegiatan bermain untuk anak usia dini, sehingga orang tua dapat mendukung proses belajar bagi anak dengan mengaplikasikan kegiatan belajar yang sesuai untuk anak usia dini dalam kehidupan sehari-hari.

2. Guru

Dengan hasil penelitian ini diharapkan dapat bermanfaat sebagai bahan masukan untuk evaluasi diri (self evaluation), terutama dalam mengembangkan mutu pembelajaran dalam merancang kegitan serta untuk lebih memperkaya strategi guru dalam mengajar, menambah pengetahuan dan keterampilan tentang finger painting, sehingga dapat diaplikasikan dalam merancang program perkembangan kemampuan

\section{KAJIAN TEORI}

\section{A. Perkembangan Bahasa Anak UsiaDini}

Standar isi tentang tingkat pencapaian perkembangan bahasa anak usia 4-5 tahun yang diatur dalam Peraturan Menteri Pendidikan Dan Kebudayaan Republik Indonesia Nomor 146 Tahun 2014 Tentang Kurikulum 2013 Pendidikan Anak Usia Dini yang menyebutkan bahwa indikator tingkat pencapaian perkembangan menulis anak usia 4-5 tahun adalah menulis huruf-huruf yang dicontohkan dengan cara meniru.

\section{B. Finger Painting}

Finger Painting ialah kegiatan membuat suatu pola pada adonan atau pasta dengan jari jemari di atas bidang gambar. Kegiatan melukis ini menggunakan tangan sebagai kegiatan sensori motor dan memberikan pengalaman langsung terhadap perkembangan otot-otot halus anak.

\section{Hasil Penelitian yang Relevan}

Ada beberapa hasil penelitian yang dilakukan orang lain yang relevan dengan penelitian ini diantaranya penelitian yang dilakukan oleh oleh Aty Nurbaiti dengan judul
"Pengaruh Latihan Menggambar Terhadap Kemampuan Menulis Anak Usia 5-6 Tahun". Hasil dari penelitian ini menunjukan bahwa adanya pengaruh dari pemberian latihan menggambar yang diberikan oleh guru terhadap kemampuan menulis anak usia 5-6 tahun di TK Islam Al-Azhar 9 Kembangan Jakarta Barat. Dari Penelitian ini terlihat bahwa dalam mengembangkan kemampuan menulis anak dapat dilakukan salah satunya dengan memberikan pelatihan mengambar.

Penelitian lainnya yang dilakukan oleh Bella Ridha Sanytiasa dengan judul "Upaya Meningkatkan Kemampuan Menulis Anak Usia 5-6 Tahun Melalui Bermain Play Dough di RA Apel Cilandak Timur". Hasil dari penelitian ini menjelaskan bahwa bermain play dough sangat membantu pendidikan dalam memberikan pengajaran bahasa terutama meningkatkan kemampuan menulis anak. Selain itu juga dapat memberikan informasi tambahan bagi pendidik maupun orangtua dalam memberikan pelajaran menulis kepada anak sebaiknya menggunakan bermain play dough.

\section{METODE PENELITIAN}

\section{A. Tempat dan WaktuPenelitian}

Penelitian ini dilaksanakan di TK

Latihan II yang terletak di Jl. Halimun No. 2B Setiabudi, Jakarta Selatan. Penelitian ini dilaksanakan pada semester 1 tahun ajaran 2015-2016 yakni bulan Agustus 2015 Januari 2016

\section{B. SubjekPenelitian}

Penelitian tindakan kelas ini dilakukan di TK Negeri Latihan II. Subjek penelitian tindakan kelas ini Subjek penelitian tindakan kelas ini yaitu anak-anak kelompok A usia 4-5 tahun yang berjumlah 19 orang.

\section{Desain Penelitian TindakanKelas}

Penelitian Tindakan Kelas (PTK) merupakan penelitian tindakan (action reaserch) yang dilaksanakan oleh guru di dalam kelas (Ekawarna, 2010: 4). Penelitian yang dilakukan oleh guru di kelasnya sendiri melalui refleksi diri dengan tujuan memperbaiki kinerjanya sehingga hasil belajar siswa menungingkat (Aqib, 2009: 3). Menurut Arikunto (2008: 58) penelitian tindakan kelas 
adalah tindakan yangdilakukan dikelas dengan tujuan memperbaiki atau meningkatkan mutu praktik pembelajaran.

Desain intervensi tindakan/ rancangan siklus penelitian tindakan kelas ini menggunakan model Kemmis and Taggart. Adapun prosedur kerja dalam penelitian tindakan kelas menurut Kemmis and Taggart (1990) meliputi tahap-tahap (a) perencanaan (planning); (b) tindakan (action); (c) pengamatan (observation); (d) refleksi (reflection). Model pelaksanaan PTK ini menggunakan acuan model siklus PTK yang dikembangkan oleh Kemmis \& Taggart (1990), yang digambarkan sebagai berikut:

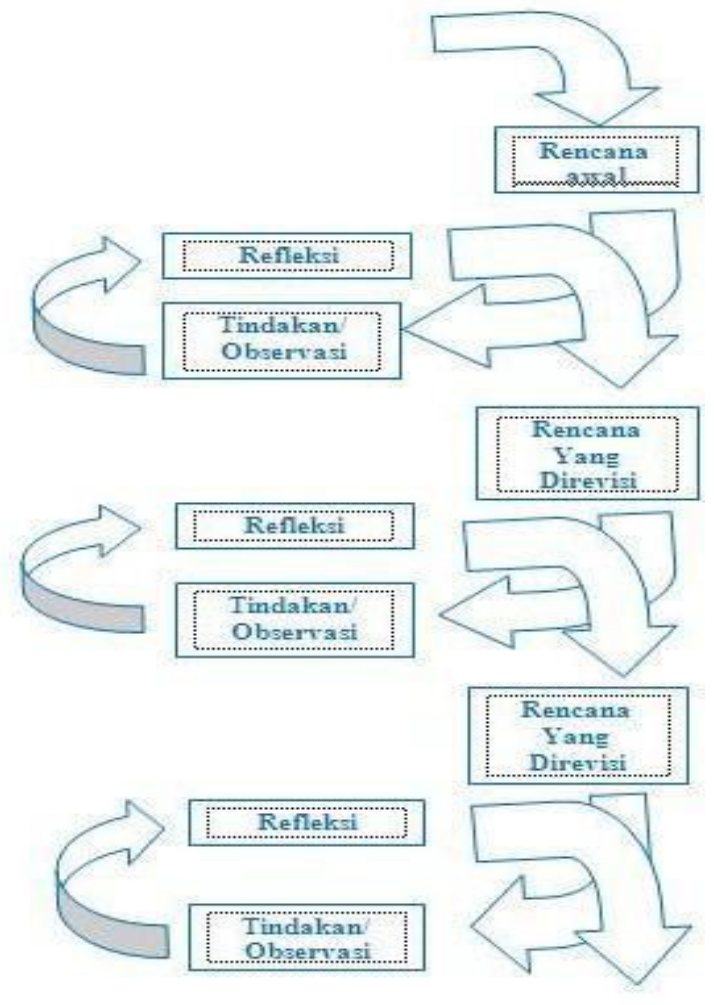

Gambar 1. Penelitian Tindakan Kelas Model Kemmis \& Taggart

D. Prosedur Penelitian TindakanKelas

1. Pra Penelitian

Pra penelitian ini dilakukan sebelum dilaksanakannya penelitian tindakan dalam beberapa siklus penelitian. Hal ini dilakukan guna mengetahui kondisi, situasi dan kemampuan anak sebelum dilakukan penelitian, yang akan berguna bagi peneliti untuk melakukan perencanaan tindakan.
2. Gambaran rencana pelaksanaan setiap siklus adalah sebagaiberikut:

a. Perencanaan (planning) Kegiatan yang dilakukan pada tahap ini adalah sebagai berikut:

1) Menyusun rencana kegiatan harian

2) Menyiapkan bahan finger painting yang akan digunakan

3) Menyiapkan lembar kerjaanak

4) Membuat lembar observasi anak mengenai peningkatan kemampuan menulis permulaan anak melalui kegiatan finger painting

5) Membuat lembar obsevasi guru tentang cara mengajar

6) Membuat lembar observasi tentang aktifitas anak selama pembelajaran

7) Membuat lembar observasi tentang aktivitas anak selama pembelajaran

b. Pelaksanaan tindakan (acting)

Tahap pelaksanaan/ implementasi tindakan merupakan tahap pelaksanaan proses pembelajaran di kelas. Pada tahap ini peneliti melakukan kegiatan pembelajaran seperti yang telah di rencanakan meliputi kegiatan awal, kegiatan inti, dan kegiatan penutup

c. Pengamatan (Observasi)

Pengamatan dilakukan oleh peneliti didalam kelas, yaitu pada saat pelaksanaan proses pembelajaran oleh guru. Pengematan proses pembelajaran menggunakan instrumen penelitian yang telah dibuatsebelumnya.

d. Refleksi

Refleksi dilakukan saat berakhirnya semua kegiatan pembelajaran. Pada tahap ini peneliti mendiskusikan hasil yang meliputi kelebihan dan kekurangan proses pembelajaran yang dilakukan oleh guru. Hasil refleksi ini akan digunakan sebagai acuan perbaikan untuk membuat perencanaan pada siklus berikutnya.

\section{E. Teknik Pengumpulan Data}

Teknik dan prosedur pengumpulan data yang digunakan dalam penelitian tindakan 
kelas ini yaitu :

1. Observasi

data dengan cara mengamati setiap kejadian yang sedang berlangsung dan mencatat pada lembar observasi yang telah dibuat sebelumnya yaitu lembar observasi peningkatan kemampuan menulis anak, lembar aktifitas guru dan lembar observasi anak.

2. Wawancara

Peneliti mewawancarai guru kelas untuk menanyakan hal apa saja yang akan diteliti dengan pertanyaan yang sudah disiapkan oleh peneliti, agar peneliti mempunyai data dan informasi awal yang akurat tentang permasalahan yang terjadi di dalam kelas agar peneliti bisa menentukan tindakan apa saja yang akan dilakukan selama penelitian.

\section{Dokumentasi}

Teknik yang dilakukan untuk memperoleh data langsung dari tempat penelitian seperti laporan kegiatan, fotofoto kegiatan pembelajaran dan data data lain yang diperlukan.

\section{F. Teknik Analisis Data}

Analisis data dilakukan dengan dengan menggunakan statistiK deskriptif sederhana (Tampubolon dalam Muslich, 2014: 17). Statistik deskriptif adalah prosedur matematika sederhana yang berfungsi untuk menyederhanakan, merangkum, dan mengorganisasi sejumlah data yang relatif besar dengan rumus:

$$
\mathrm{P}=\frac{F}{N} \times 100 \%
$$

Keterangan:

$\mathrm{P}=$ Presentase

$\mathrm{F}=$ Jumlah siswa yang terlibat dalam aspek $\mathrm{N}=$ Jumlah seluruh siswa dalam kelas.

\section{G. Indikator Keberhasilan}

Pada penelitian ini, anak diharapkan mampu menulis huruf-huruf yang terdapat pada kartu kata dengan cara meniru melalui kegiatan finger painting. Penelitian ini dikatakan berhasil apabila $75 \%$ dari jumlah anak didik yang berjumlah 19 orang memperoleh skor (bintang) 3 berkembang sesuai harapan (BSH) pada indikator mampu meniru huruf-huruf yang dicontohkan.

\section{HASIL DAN PEMBAHASAN}

A. Hasil Penelitian

1. Temuan Umum

TK Negeri Latihan II terletak di Jalan Halimun Raya No. 2 Kelurahan Guntur Kecamatan Setiabudi Jakarta Selatan. TK Negeri Latihan II berdiri sejak TK Negeri Latihan II didirikan pada Tahun 1975 dengan luas tanah $526 \mathrm{~m} 2$ luas bangunan $300 \mathrm{~m} 2$ dan mulai operasionalnya pada Tahun 1976. Pendirian TK Negeri Latihan II didasari atas kepentingan Siswa Sekolah Pendidikan Guru (SPG) untuk Latihan Praktek Mengajar, dan pada saat ini masih digunakan mahasiswa Universitas Negeri Jakarta Jurusan Psikologi sebagai tempat penelitian, observasi dan praktek lapangan. TK Negeri Latihan II memiliki 7 orang tenaga kependidikan, 6 orang tenaga pendidik (guru) sudah memiliki gelar S1 PAUD, 5 orang diantara guru tersebut merupakan pegawai negeri sipil (PNS) sedangkan 1 orang lainnya lulusan SMA. TK Negeri Latihan II memiliki murid kurang lebih 86 anak yang dibagi menjadi 4 kelas yaitu Kelompok Bermain sebanyak 6 anak, Kelompok A sebanyak 19 anak, Kelompok B-1 sebanyak 30 anak, Kelompok B-2 sebanyak 30 anak.

Visi TK Negeri Latihan II adalah terwujudnya anak usia dini yang berkepribadian dan berakhlak Mulia, Percaya diri, Mandiri serta berkembangnya potensi anak sejak dini. Misi TK Negeri Latihan II adalah:

a. Mendidik anak berkepribadian Mulia dengan dasar Taqwa kepada Tuhan Yang Maha Esa

b. Melaksanakan kegiatan pembelajaran dengan bermain sambil belajar dan belajar seraya bermain

c. Melatih kemandirian dalam kegiatanbelajar mengajar

d. Menciptakan suasana belajar yang aktif, kreatif, inovatif dan menyenangkan. 
2. Temuan Khusus

a. Wawancara

Nama : Wirastri Setyorini, S.Pd

Jabatan : Guru Kelas

Tabel 1. Hasil Wawancara

\begin{tabular}{|c|c|}
\hline Pertanyaan & Jawaban \\
\hline $\begin{array}{l}\text { 1. Bagaimana perkembangan } \\
\text { kemampuan menulis awal } \\
\text { anak di kelas A ini? }\end{array}$ & $\begin{array}{l}\text { 1. Karena ini baru semester } 1 \\
\text { jadi kemampuan menulis di } \\
\text { kelas ini masih kurang, } \\
\text { tetapi ada beberapa anak } \\
\text { yang sudah bisa menulis } \\
\text { nama dengan benar. }\end{array}$ \\
\hline $\begin{array}{l}\text { 2. Strategi apa yang } \\
\text { dilakukan guru di kelas A } \\
\text { ini untuk meningkatkan } \\
\text { kemampuan menulis } \\
\text { anak? }\end{array}$ & $\begin{array}{l}\text { 2. Strateginya itu setiap pagi } \\
\text { anak-anak melakukan } \\
\text { absen dengan cara menulis } \\
\text { nama mereka pada lembar } \\
\text { absen di depan kelas, } \\
\text { selain itu juga } \\
\text { memberikan latihan dari } \\
\text { buku 'ayo menulis' } \\
\text { dibuku tersebut anak } \\
\text { mengerjakan tugas } \\
\text { dengan metode dot-to dot } \\
\text { sehingga anak dapat } \\
\text { terlatih menulis. }\end{array}$ \\
\hline $\begin{array}{l}\text { 3. Tindakan apa yang } \\
\text { dilakukan untuk anak yang } \\
\text { masih kurang dalam } \\
\text { kemampuan } \\
\text { permulaan? }\end{array}$ & $\begin{array}{l}\text { 3. Karena masih kelompok } \\
\text { A, kita (guru) masih } \\
\text { melihat perkembangan } \\
\text { menulis anak- anak } \\
\text { sejauh ini cukup kita } \\
\text { (guru) mendampingi } \\
\text { apabila ada anak yang } \\
\text { merasa kesulitan. }\end{array}$ \\
\hline $\begin{array}{l}\text { 4. Media apa saja yang biasa } \\
\text { dilakukan pada saat } \\
\text { mengajar? }\end{array}$ & $\begin{array}{l}\text { 4. Media yang sering } \\
\text { digunakan yaitu gambar- } \\
\text { gambar. }\end{array}$ \\
\hline $\begin{array}{l}\text { 5. Apakah anak kelas A ini } \\
\text { pernah melakukan } \\
\text { kegiatan finger painting } \\
\text { sebelumny? }\end{array}$ & $\begin{array}{l}\text { 5. Belum pernah, untuk } \\
\text { kelas A ini belum pernah } \\
\text { melakukan kegiatan } \\
\text { finger painting biasanya } \\
\text { hanya menggunakan cat } \\
\text { air. }\end{array}$ \\
\hline
\end{tabular}

b. Observasi

Tabel 2. Hasil Observasi

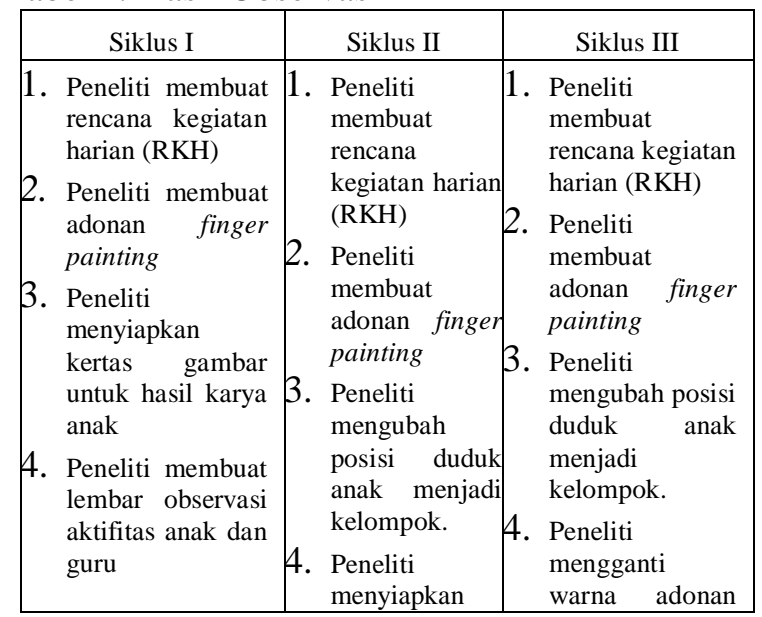

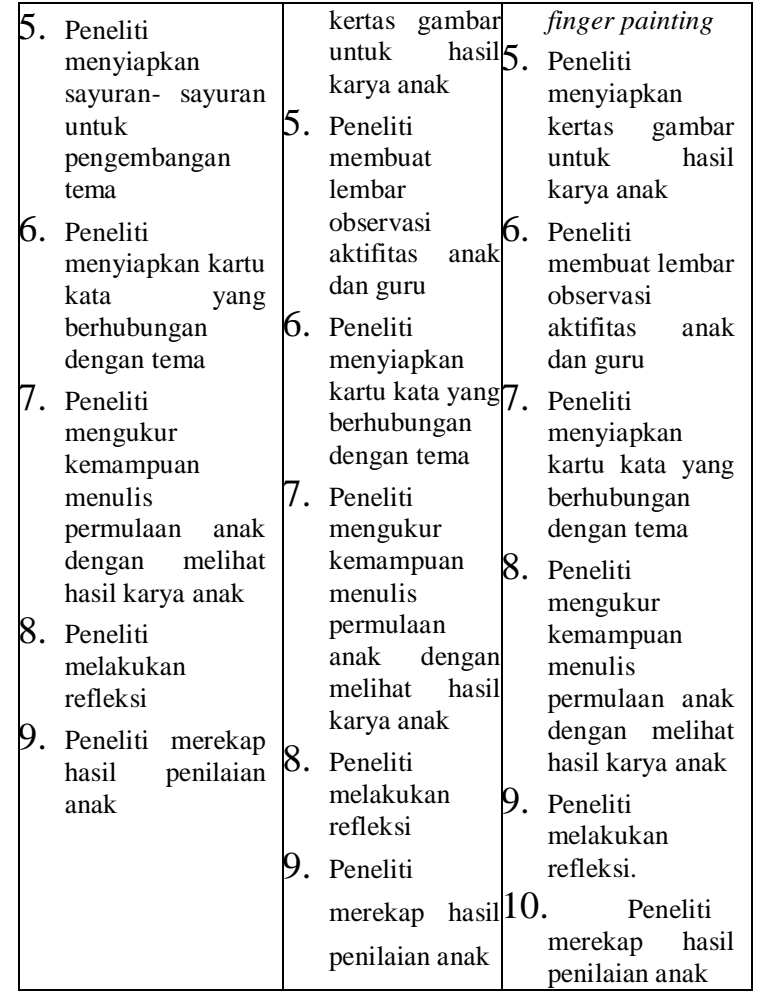

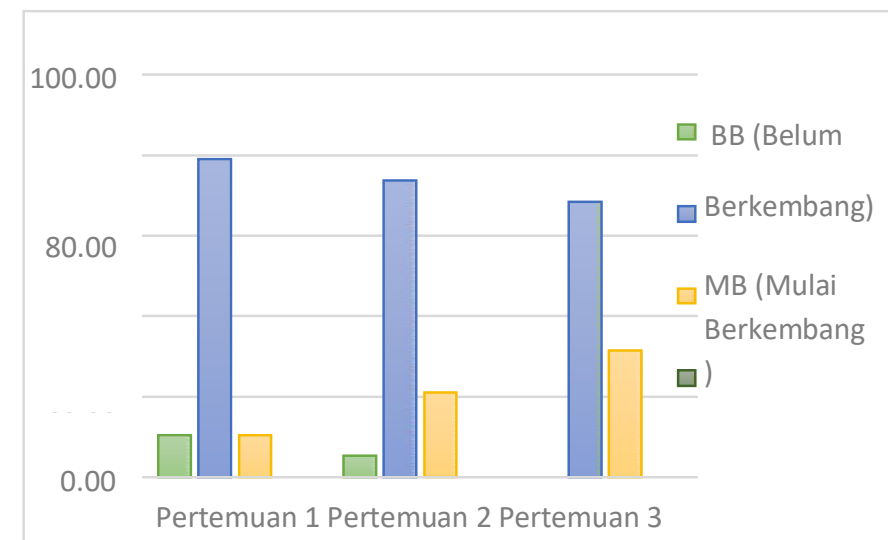

Grafik 1. Hasil Penilaian Siklus I

Tabel 3. Presentasi Tingkat Keberhasilan Siklus I

\begin{tabular}{|c|c|c|c|c|}
\hline $\begin{array}{c}\text { Pertemuan } \\
\text { Ke }\end{array}$ & $\begin{array}{c}* \\
(\mathrm{BB})\end{array}$ & $\begin{array}{c}* * \\
(\mathrm{MB})\end{array}$ & $\begin{array}{c}* * * \\
(\mathrm{BSH})\end{array}$ & $\begin{array}{c}* * * * \\
(\mathrm{BSB})\end{array}$ \\
\hline 1 & 2 & 15 & 2 & 0 \\
\hline 2 & 1 & 14 & 4 & 0 \\
\hline 3 & 0 & 13 & 6 & 0 \\
\hline Jumlah & 3 & 42 & 12 & 0 \\
\hline$\%$ & $5,26 \%$ & $73,69 \%$ & $21,05 \%$ & $0 \%$ \\
\hline
\end{tabular}


Grafik 2. Hasil Penilaian Siklus II

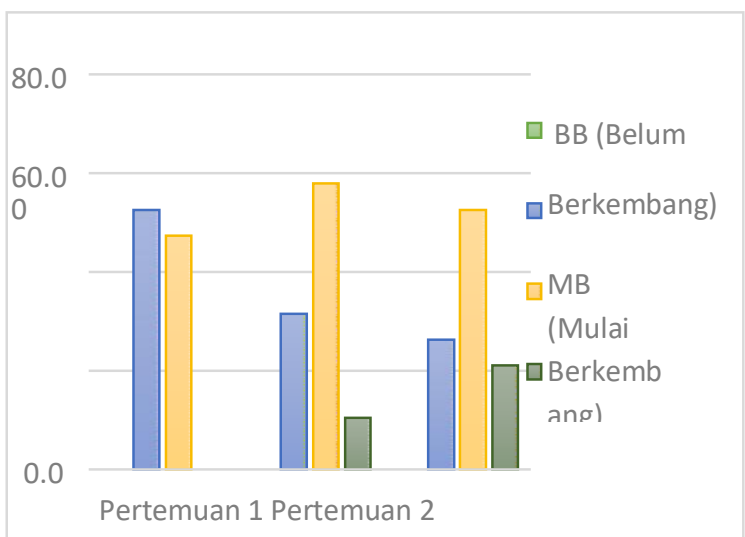

Tabel 4. Presentasi Tingkat Keberhasilan Siklus II

\begin{tabular}{|c|c|c|c|c|}
\hline $\begin{array}{c}\text { Pertemuan } \\
\mathrm{Ke}\end{array}$ & $*$ & $* *$ & $* * *$ & $* * * *$ \\
$(\mathrm{BB})$ & $(\mathrm{MB})$ & $(\mathrm{BSH})$ & $(\mathrm{BSB})$ \\
\hline 1 & 0 & 10 & 9 & 0 \\
\hline 2 & 0 & 6 & 11 & 2 \\
\hline 3 & 0 & 5 & 10 & 4 \\
\hline Jumlah & 0 & 21 & 30 & 6 \\
\hline$\%$ & $0 \%$ & $36.84 \%$ & $52.63 \%$ & $10.53 \%$ \\
\hline
\end{tabular}

Grafik 3. Hasil Penilaian Siklus III
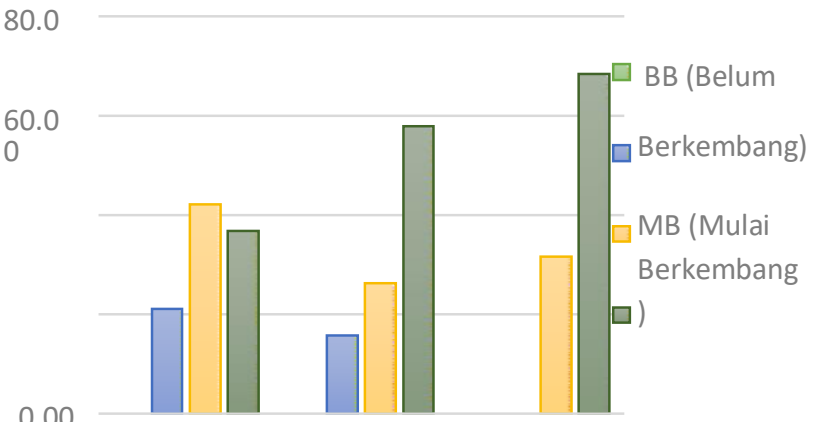

Pertemuan 1 Pertemuan 2 Pertemuan 3
Tabel 5. Presentasi Tingkat Keberhasilan Siklus III

\begin{tabular}{|c|c|c|c|c|}
\hline $\begin{array}{c}\text { Pertemuan } \\
\text { Ke }\end{array}$ & $\begin{array}{c}* \\
(\mathrm{BB})\end{array}$ & $\begin{array}{c}* * \\
(\mathrm{MB})\end{array}$ & $\begin{array}{c}* * * \\
(\mathrm{BSH})\end{array}$ & $\begin{array}{c}* * * * \\
(\mathrm{BSB})\end{array}$ \\
\hline 1 & 0 & 4 & 8 & 7 \\
\hline 2 & 0 & 3 & 5 & 11 \\
\hline 3 & 0 & 0 & 6 & 13 \\
\hline Jumlah & 0 & 7 & 19 & 31 \\
\hline$\%$ & $0 \%$ & $12,28 \%$ & $33,33 \%$ & $54,39 \%$ \\
\hline
\end{tabular}

Tabel 6. Presentase Peningkatan Setiap Sikus

\begin{tabular}{|c|c|c|c|c|}
\hline $\begin{array}{c}\text { Siklus } \\
\text { Ke }\end{array}$ & $\begin{array}{c}* \\
(\mathrm{BB})\end{array}$ & $\begin{array}{c}* * \\
(\mathrm{MM})\end{array}$ & $\begin{array}{c}* * * * \\
(\mathrm{BSH})\end{array}$ & $(\mathrm{BSB})$ \\
\hline 1 & $5,26 \%$ & $73,69 \%$ & $21,05 \%$ & $0 \%$ \\
\hline & $(-5,26 \%)$ & $(-36,85 \%)$ & $31,58 \%$ & $10,53 \%$ \\
\hline 2 & $0 \%$ & $36,84 \%$ & $52,63 \%$ & $10,53 \%$ \\
\hline & - & $(-24,56 \%)$ & $(-19.30 \%)$ & $43,86 \%$ \\
\hline $\mathbf{3}$ & $\mathbf{0 \%}$ & $\mathbf{1 2 , 2 8} \%$ & $\mathbf{3 3 , 3 3 \%}$ & $\mathbf{5 4 , 3 9 \%}$ \\
\hline
\end{tabular}

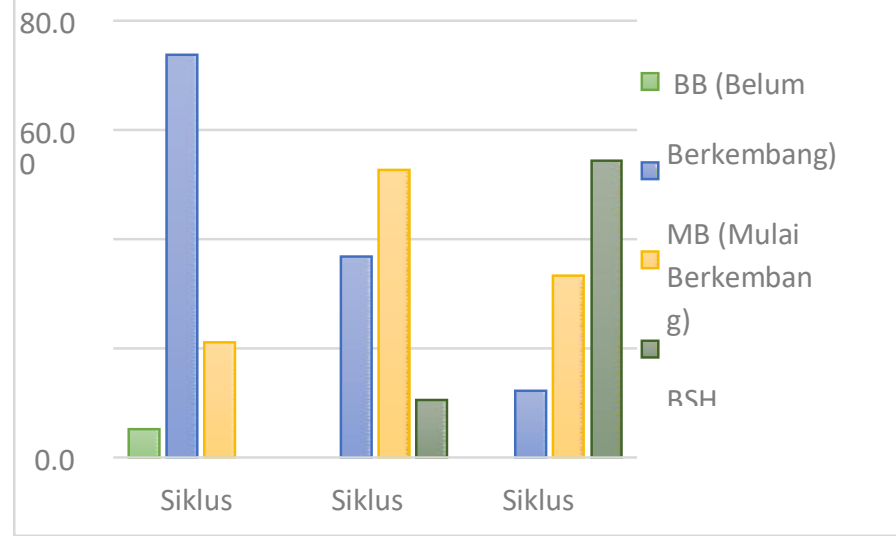

Grafik 4. Hasil Penilaian Setiap Siklus

\section{B. Pembahasan}

Pelaksanaan Siklus I, ketercapaian penelitian masih jauh dari kriteria yang telah ditentukan. Ketika tindakan dilakukan, adonan 
finger painting yang digunakan pada siklus ini adalah adonan yang dibuat dari tepung jagung yang teksturnya terlalu padat sehingga menyulitkan anak- anak untuk menggambar sehingga hasil karya yang dihasilkan anak kurang maksimal. Namun di samping kekurangan tersebut anak-anak sangat antusias mengerjakan kegiatan finger painting. Namun di samping kekurangan tersebut, anak-anak sangat antusias mengerjakan kegiatan ini karena kegiatan semacam ini jarang dilakukan di dalam pembelajaran sebelumnya. Peneliti pun menyiapkan rencana yang lebih baik dibandingkan sebelumnya untuk meningkatkan ketercapaian penelitian.

Pada siklus II, masih terdapat kekurangam saat tindakan yang dilakukan yaitu terkait dengan kartu kata yang diberikan kepada anak terlalu panjang sehingga banyak anak yang kesulitan untuk meniru kata tersebut. Adonan finger painting yang digunakan pada siklus II ini cukup efektif karena teksturnya yang kental memudahkan anak untuk menulis dan gampang untuk dibersihkan. Namun hasil dari pelaksanaan siklus II lebih baik dari siklus sebelumnya, terdapat peningkatan ketercapaian penelitian. Peneliti pun menyiapkan strategi dan rencana yang lebih baik lagi agar di siklus selanjutnya bisa tercapai keberhasilan penelitian.

Pada siklus III, kekurangan-kekurangan yang terjadi pada siklus sebelumnya tidak terjadi lagi dan tindakan yang dilakukan jauh lebih baik. Dibandingkan dengan siklus sebelumnya, di siklus III ini tercapai keberhasilan penelitian lebih dari presentase yang diharapkan.

\section{SIMPULAN DAN SARAN}

\section{A. Simpulan}

Penelitian tindakan kelas ini dilakukan di kelompok A TK Negeri Latihan II selama 3 siklus, 1 siklus terdiri dari 3 pertemuan dimana masing-masing pertemuan peneliti mengajarkan menulis permulaan melalui kegiatan finger painting. Setiap siklus terdapat perencanaan, pelaksanaan, observasi dan refleksi.

Penilaian dilakukan menggunakan indikator menuliskan huruf-huruf yang dicontohkan dengan cara meniru, serta, menggunakan 4 kriteria pada indikator yaitu belum berkembang $(\mathrm{BB})$, mulai berkembang
(MB), berkembang sesuai harapan (BSH) dan berkembang sangat baik (BSB) yang dilakukan setiap hari selama 3 siklus.

Berdasarkan hasil penelitian, maka dapat disimpulkan bahwa melalui kegiatan finger painting mampu meningkatkan kemampuan menulis permulaan anak yaitu menulis hurufhuruf yang dicontohkan dengan cara meniru. Kemampuan tersebut dapat dilihat dari tingkat ketercapaian indikator pada setiap siklus. Siklus I menunjukkan bahwa pada indikator (menuliskan huruf-huruf yang dicontohkan dengan cara meniru) terdapat kriteria Belum Berkembang (BB) sebanyak 5.26\% dan Mulai Berkembang (MB) sebesar 73.69\%. Sedangkan kriteria Berkembang Sesuai Harapan (BSH) sebesar 21.05\% dan yang Berkembang Sangat Baik (BSB) tidak ada atau sebesar 0\%. Kemudian pada Siklus II, kriteria Belum Berkembang (BB) sudah tidak ada atau 0\% dan Mulai Berkembang (MB) sebesar $36.84 \%$. Sedangkan kriteria Berkembang Sesuai Harapan (BSH) mengalami peningkatan sebesar $31.58 \%$ menjadi $52.63 \%$ dan yang Berkembang Sangat Baik (BSB) meningkat menjadi 10.53\%. Pada Siklus III kriteria Belum Berkembang (BB) sudah tidak ada atau 0\% dan Mulai Berkembang (MB) sebesar 12.28\%. Sedangkan kriteria Berkembang Sesuai Harapan (BSH) sebesar 33.33\% dan kriteria Berkembang Sangat Baik (BSB) meningkat $43.86 \%$ menjadi $54.39 \%$.

\section{B. Saran}

Berdasarkan hasil penelitian tersebut, maka saran yang dapat diberikan adalah sebagai berikut:

\section{Guru}

Dalam meningkatkan kemampuan menulis permulaan anak dapat menggunakan kegiatan yang lebih menarik untuk anak, yang tidak membuat cepat bosan dan menyenangkan bagi anak, salah satunya kegiatan finger painting.

2. Sekolah

Sekolah sebaiknya menyediakan lebih banyak lagi alat, bahan, media pembelajaran dan fasilitas yang menunjang serta mendukung berlangsungnya kegiatan pembelajaran.

3. Orangtua

Bagi orangtua hendaknya menerapkan kegiatan ini dirumah agar dapat melatih 
kemampuan menulis permulaan anak.Anak dan orangtua juga dapat bereksperimen mengenai percampuran warna pada pembuatan adonan finger painting.

\section{DAFTAR PUSTAKA}

Arikunto, S. (2007). Penelitian tindakan kelas. Jakarta: Bumi Aksara.

Aqib, Z. (2009). Penelitian tindakan kelas. Bandung: Yrama Widya.

Ekawarna, (2010). Penelitian tindakan kelas. Jakarta: Gaung Persada.

Moeslichatoen, R. (2004). Metode pengajaran di taman kanak-kanak. Jakarta: Rineka Cipta.

Munandar, U. (2009). Mengembangkan bakat dan kreatifitas anak sekolah. Jakarta: Gramedia.
Nurbaiti, A. (2011). Pengaruh latihan menggambar terhadap kemampuan menulis anak usia 5-6 tahun. Skripsi Program Studi PAUD UAI. Tidak Diterbitkan.

Permendikbud Nomor 146 Tahun 2014 tentang standar pendidikan anak usia dini.

Sanytiasa, B.R. (2014). Upaya meningkatkan kemampuan menulis anak usia 5-6 tahun melalui bermain play dough. Skripsi Program Studi PAUD UAI. Tidak Diterbitkan.

Seefeldt, C.B., Wasik A. (2008). Pendidikan anak usia dini menyiapkan anak usia tiga, empat, lima tahun masuk sekolah. Jakarta. 